\title{
True and fake red layers \\ on the objects from archaeological and historical context: microscopic observations
}

\author{
Joanna Trąbska ${ }^{1}$, Barbara Trybalska² \\ ${ }^{1}$ Rzeszów University, Institute of Archaeology; ul. Moniuszki 10, 35-015 Rzeszów; \\ e-mail: joanna.trabska@archeologia.rzeszow.pl \\ ${ }^{2}$ AGH University of Science and Technology, Department of Material Engineering and Ceramics; \\ al. Mickiewicza 30,30-059 Krakow, Poland; e-mail: barbara.trybalska@wp.pl
}

(C) 2014 Authors. This is an open access publication, which can be used, distributed and reproduced in any medium according to the Creative Commons CC-BY 4.0 License requiring that the original work has been properly cited.

Received: 10 September 2013; accepted: 17 June 2014

\begin{abstract}
Colored layers on surfaces of objects associated with archaeological and historical context may be of various origins: natural or intentional and in numerous cases their exact identification is not obvious, especially for thousand-year-old objects. Yet, the diagnosing of their nature may constitute an important element for the interpretation of ancient cultures. Examples of red color layers of natural, intentional and unclear origin were chosen and observed to select criteria defining layers of uncertain parentage.
\end{abstract}

Keywords: archaeology, red layers, paintings, weathering crusts

\section{INTRODUCTION}

Colored layers on surfaces of objects associated with archaeological and historical context may have been produced by humans deliberately or "made" by nature; they may have arisen in a natural way, but have been generated by the specific cultural context. Colorful layer may appear because of restorers' interventions: introduction of a colored layer consciously or because of product time discoloration. In extreme cases, one must reckon with counterfeiting. In any situation, it is important to identify a substance which formed the layer and to determine how it contacts with the ground, how thick and how homogeneous it is; perhaps also to detect a specific painting technique or traces of tools employed in a painting process. It is crucial to define the natural and cultural context from which the item originates.
Red was the first true color attractive to humans (Petru 2006), and evidences of interest in it reach deep into Paleolithic. In a distant time span, it is particularly difficult to distinguish between intentional and the natural colors or the imposition of one to another. Diagnosing of their nature may constitute an important element for the interpretation of the dawn of human culture.

The problem of discrimination between intentional and natural red layer refers to not only paintings but also fine-grained or cryptocrystalline iron-bearing crusty concentrations of other origin. They may be remnants of rubbing red powders into various supports (Behrmann \& Gonzales 2009 - Fig. 5), even very specific, like a cemented, phosphatized ash from a hearth dated to $58,000 \mathrm{BP}$ (Sibudu, South Africa, Wadley 2010). Red crusts appear on skeletal surfaces due to unknown actions: rubbing a powder into a body, rubbing it into 
a skeleton, applying a suspension, spraying a red dust or others. Cracks and crevices may have been infilled with red remnants after exploitation of a red raw material; it is a case of the Lovas site (Hungary \& Dobosi 2006). Many sculptures and reliefs, now discolored, are believed to have been painted but only microscopic traces may support these hypotheses (Roussot 1994, Behrmann \& Gonzales 2009).

Archaeological artifacts may have become casually contaminated by red powder dispersed in a sediment due to intentional actions (such concentrations are known from numerous sites, e.g. the Fumane cave, Broglio et al. 2007), due to their immersion in red ash layers (present e.g. at the Dolni Věstonice I and Milovice sites, Moravia \& Oliva 2007) or natural red regolith of terra rosa type, abundant in numerous southern European caves (e.g. Odile \& Plassard 1995). Nevertheless, to the authors' knowledge, no hard evidence of such contamination has been proved so far.

Paintings and irregular patches that happen to occur together (e.g. the Aurignacian paintings from the Fumane cave, Broglio et al. 2007) can be discerned when the two are compared on the basis of microstratigraphy and petrographic analyses. In many dubious cases, an intentional action of painting may be identified due to specific appearance of a smoothened underground, infilling and evening of microundulation (e.g. Trąbska 2001); however, for many rock, cave, shell or stone paintings it does not occur (e.g. Broglio et al. 2007: 167).

Usually, thickness of paintings executed with mineral pigments balances close to $0.2 \mathrm{~mm}$ (e.g. Roy 1993, Berry 2007). The pigments used to be very fine-grained and of homogeneous size, due to careful grinding (the phenomenon observed also for the rock paintings, e.g. Hoz de Vicente, Hernanz et al. 2010) but their particular appearance will always depend on an individual workshop or painting technique. However, micromorphological features of a pigment itself may appear indicative especially because ground iron-bearing pigments tend to preserve their parental microstructure (Trąbska et al., manuscript). In this way, the particles micromorphology may indicate an external source of a raw material, different from in situ source. In some cases, hematite ordering may indicate at a pigment origin (Trąbska \& Gaweł 2007, Hernanz et al. 2010). Unfortunately, detailed comparative analyses may be misleading.
Microstructure and chemical composition of a potential intentional layer may perfectly reflect the analogous features of a widespread red rocks from the surroundings. Some red paintings from the Fumane Cave were executed with a pigment of a composition identical with the pigment of the cave's terra rosa (Broglio et al. 2007).

To numerous paintings, even as ancient as Paleolithic, specific extenders used to be added (Martin 1993: 261-264, Behrmann \& Gonzales 2009). They tend to be different from an underground and the recipes are repeatable, so that their presence points at human executed panting. Analyses of organic bindings are not so promising, especially for very old crusts and paintings (e.g. Paleolithic), excluding waxes, stable within very long periods of time (Riparo Dalmeri Cave, Rosanò \& Pelizzaro 2005).

Iron compounds often precipitate on bone or shell surfaces producing brown-red and red coloration. It may appear difficult to discern results of painting, rubbing, immersing or other human actions. Influence of natural processes is suggested by domination of brownish shade (especially in a moderate climate), irregularity of patches contour, only partial covering of an object. The objects that have been interpreted as intentionally colored are usually red or cherry on a whole surface and a color shade is uniform (compare, for example, Aurignacian ivory pendants from the Betche-aux-Rotches cave, Lejeune 2007: 143). It should be remembered that some restoration processes may have altered original appearance.

Intentional layers that are most difficult to discern from natural crusts come from Paleolithic, mainly due to time span and simpler or unknown way of their execution compared to numerous younger realizations. Microscopic cross-sections of cave, rock, shell or stone paintings depict various images: panting layers are cryptocrystalline or fine-grained, usually the layers are clearly discernible from an underneath but the contact may be both sharp (especially for cryptocrystalline paint, e.g. Hoz de Vicente, Hernanz et al. 2010) or cloudy (for fine-grained paint; Fumane Cave, Broglio et al. 2007: 167; Abri Pataud, Chiotti et al. 2007). Painting layers may be inserted between layers of clay minerals, gypsum, oxalates and other secondary phases (e.g. Hoz de Vicente rock art, Hernanz et al. 2010). 
Last but not least, red colored surfaces were influenced by deterioration: continuity of the layers got lost (e.g. some paintings from the Yiwarlarlay in Australian North Territory, Watchman et al. 2000), images disappeared due to powdering (e.g. Behrmann and Gonzales point at the phenomenon for certain paintings from the Siega Verde cave, 2009). Coloration was likely present on reliefs from Cap Blanc (Roussot 1994) but its nature may be interpreted only based on the analyses of microtrace remnants. A change of phase composition of red iron pigments is less possible than for other pigments but in some circumstances it is still possible.

In this paper, selected examples of red color layers of natural, intentional and unclear origin are presented. They were identified on the objects and surfaces: (a) from an archaeological context/ historical context, (b) from natural environment, (c) obtained in experimental research. Basic information on tested material is listed in the Table 1. Observation and characteristics of the well-defined color origin layers and layers of natural origin will enhance an extraction of criteria defining layers of uncertain parentage.

Samples were observed under polarized light microscope Olympus BX 51. Further tests were carried out on the scanning microscope NanoNova FEI Company, with an ISIS Link Oxford microanalyser. Samples were covered with graphite. A low vacuum technique was applied. Samples were observed in 3D dimensions, sometimes on surfaces of thin sections.

\section{RESEARCH}

\section{Historical context unspecified. Intentional red layers}

A case: Mural paintings (Vrbnik, Croatia). Red paint layer can be implemented using a wide range of pigments, dyes and adhesives (Berrie 2007). A sample comes from a depiction of a foundation cross from ruined stone chapel. Painting layers were executed with an inorganic pigment.

Thickness of a painting layer is uneven but oscillates around $0.2 \mathrm{~mm}$. It penetrates into a very fine-grained carbonate underneath. The contact is apparent but not very sharp, as if the painting was realized on a soft underlayer. Painting layer is composed of cryptocrystalline microclusters of iron compounds and fine grains of detritic quartz, feldspars and glauconite (Fig. 1). Small red remains of the painting layer are still recognizable due to features of microstructure. Layer surface is far from being perfectly smoothened (Fig. 2) but it may have been deteriorated. Features of the red painting reflect the features of terra rosa abundant in the nearby area (Trąbska et al., Data Base of Red Ferruginous Raw Materials, manuscript).

Table 1

The origin of the layers and objects, and applied research methods

\begin{tabular}{|c|c|c|c|}
\hline Context & Subject & Site & Research methods \\
\hline $\begin{array}{l}\text { Historical context undetermined, } \\
\text { red layer is intentional }\end{array}$ & $\begin{array}{l}\text { Mural painting of unknown } \\
\text { age }\end{array}$ & Vrbnik, Krk, Croatia & PLM \\
\hline Natural layer & Weathering crusts & $\begin{array}{l}\text { Annaberg, Beveaux, Kasina } \\
\text { Wlk., Strążyski Stream (The } \\
\text { Tatra Mountains), Jawor- } \\
\text { Bolków, Jaroszowiec, Brno }\end{array}$ & PLM \\
\hline Experimental red layer & $\begin{array}{l}\text { A bone immersed in a cherry } \\
\text { suspension of an iron-bearing } \\
\text { claystone }\end{array}$ & $\begin{array}{l}\text { Authors' research, also Trąbska } \\
\text { (2009) }\end{array}$ & PLM, SEM/EDS \\
\hline $\begin{array}{l}\text { Archaeological context defined, } \\
\text { red layer of dubious origin }\end{array}$ & $\begin{array}{l}\text { A skull surface covered with a } \\
\text { red layer } \\
\text { Surface of a stony pavement } \\
\text { from a grave } \\
\text { Surface of a bone covered with } \\
\text { a red layer }\end{array}$ & $\begin{array}{l}\text { Upper Paleolithic site Brno II } \\
\text { (Moravia, Czech) } \\
\text { Neolithic site Książnice } \\
\text { (Poland) } \\
\text { The Przeworsk Culture site, } \\
\text { Gać (Poland) }\end{array}$ & $\begin{array}{l}\text { PLM, SEM/EDS } \\
\text { PLM, SEM/EDS } \\
\text { PLM }\end{array}$ \\
\hline
\end{tabular}




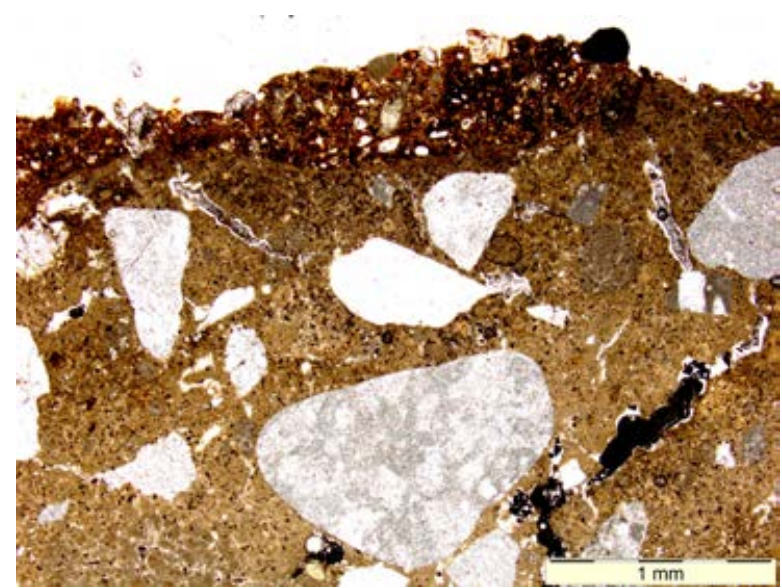

Fig. 1. Mural painting, Vrbnik, Croatia. Red layer of an uneven thickness, cracky and grainy, penetrating into the substrate. PLM, one polarizer

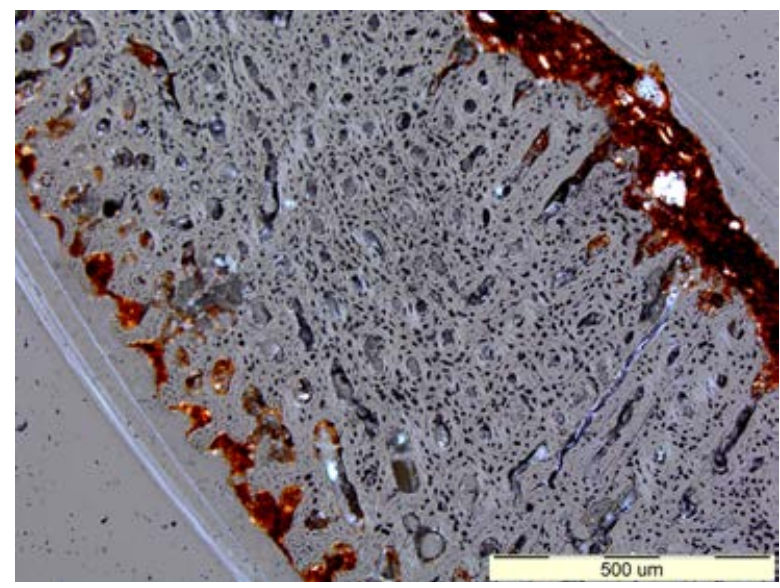

Fig. 3. A cross-section of a colored bone. The inner part on the right side of the photograph. Polarizer partially crossed

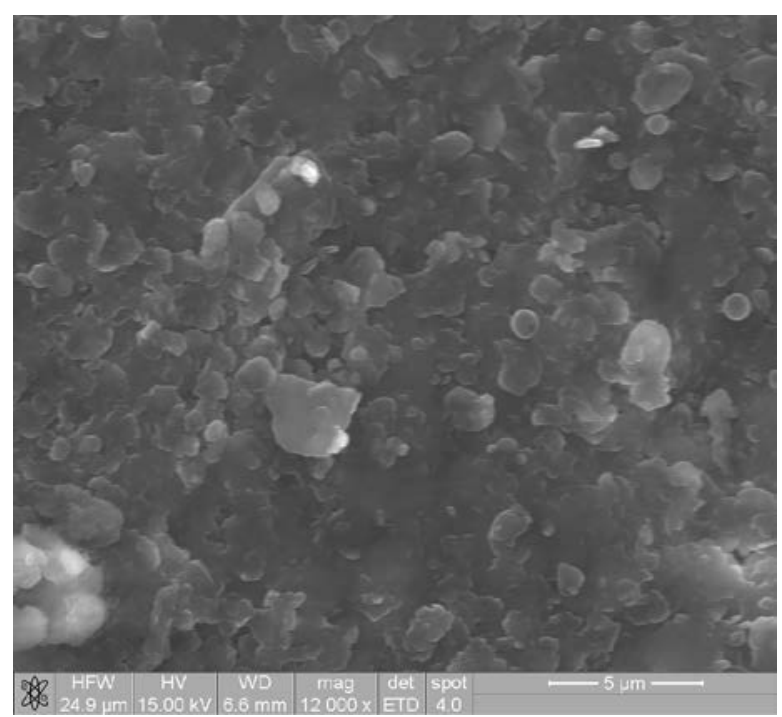

Fig. 5. A fragment of a red layer with erythrocytes and sheets of clay minerals. Magnification 12,000x

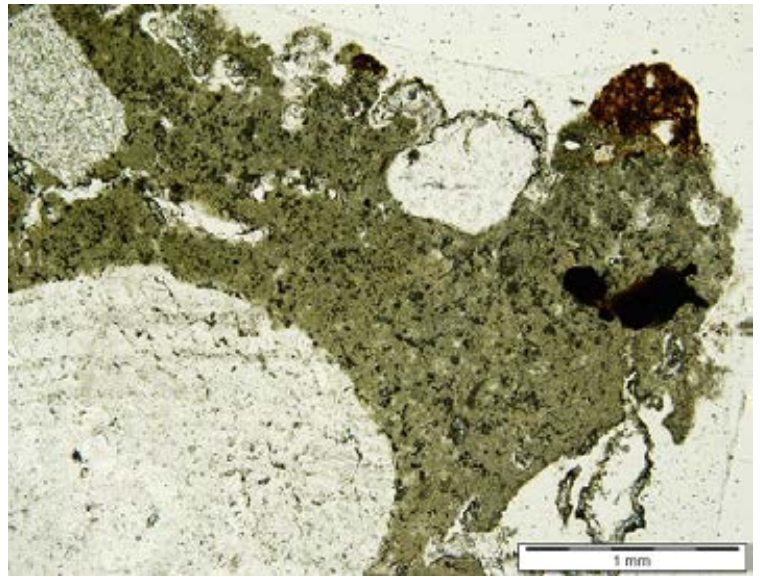

Fig. 2. A remnant of a mural painting from Vrbnik, still recognizable as part of the painting layer. PLM, one polarizer

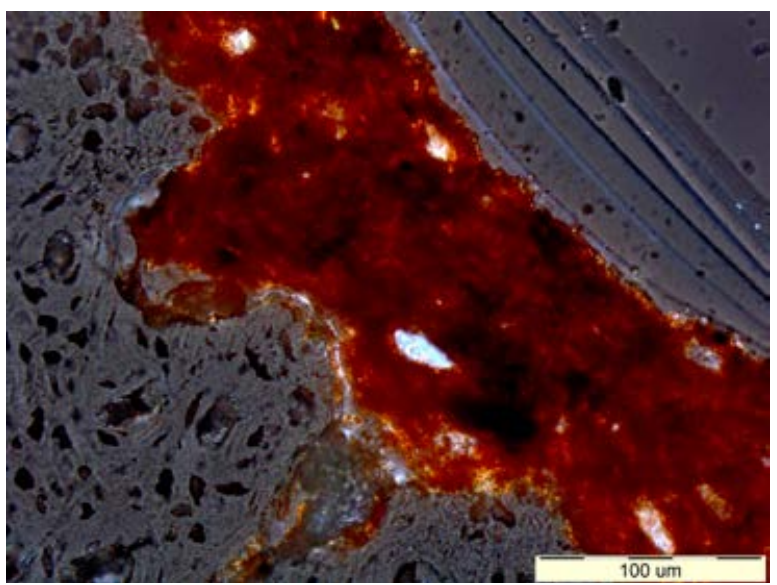

Fig. 4. A fragment of a red layer with visible compact mineral sheets. Polarizers partially crossed

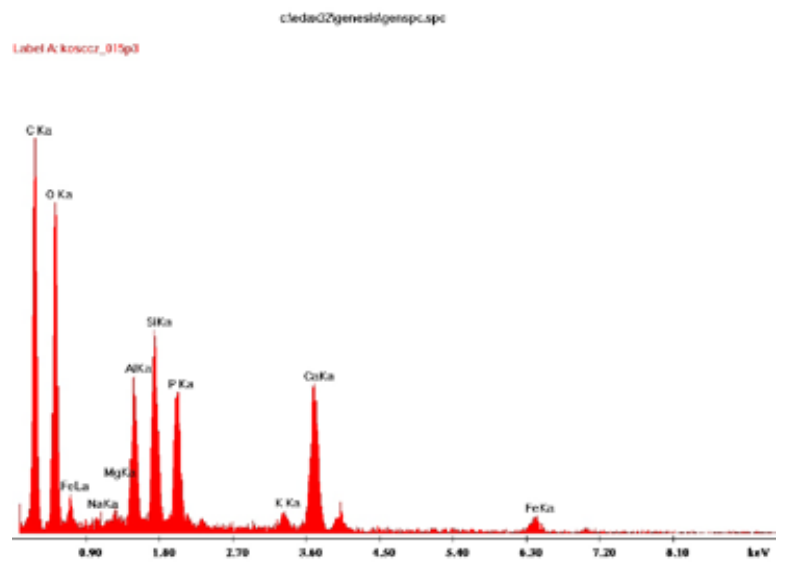

Fig. 6. EDS spectrum of the red layer. Strong apatite signal is worth noting 


\section{Context: the experiment}

The experiment involved immersing of a bone in a suspension manufactured from a mixture of Lower Triassic cherry claystone and water. Thinwalled bone, of whitened and bleached surface belonged to a small animal and was found in the field. The bone was immersed for a few minutes.

Both surfaces of the bones and large number of pores and channels have been covered or filled with red suspension (Fig. 3). The layer is homogeneous, consists of sheet minerals, cryptocrystalline iron-compound lumps and detritic components of the parental rock (Figs 3,4). Parallel clay sheets arrangement remains recognizable. The surface of red layer is smooth, but not perfectly. The thickness does not exceed $0.2 \mathrm{~mm}$. Similar characteristics were observed in the case of shells submerged in the same suspension (Trąbska 2009).

SEM/EDS analysis reveals predominantly flaky clay minerals and single erythrocytes; the latter may be explained by young, "non-archaeological" age of the bone (Fig. 5). The chemical composition of the sample revealed bone calcium and phosphorus; the other elements reflect a chemical composition of the Baranów clays (Fig. 6) (Trąbska et al. Data Base of Red Ferruginous Raw Materials, manuscript).

\section{Context: natural "layers" of weathering crusts}

In consequence of weathering processes, thin red crusts form on various rocks surfaces. Some of these layers may illusionary resemble layers of painting or other intentionally executed layers (Figs 7-10, esp. Figs 9, 10, 13); examples of their variability are presented on the photographs.

Annaberg (Erzgebirge, Germany). Sample was collected in the village of Annaberg, Erzgebirge, in an artificial outcrop. A granitoide boulder, approximately with a diameter of $3 \mathrm{~cm}$, was completely covered with a red crust of cryptocrystalline iron compounds. In the PLM image it appears to be a quite thick (about $1 \mathrm{~mm}$ ), almost opaque layer with scarce irregular voids, filled with iron compounds. Cryptocrystalline iron oxyferroxides penetrate into the surface of the granitoide and provoke scaling off the most external rock parts, as well as fill into the natural cracks (Fig. 7).

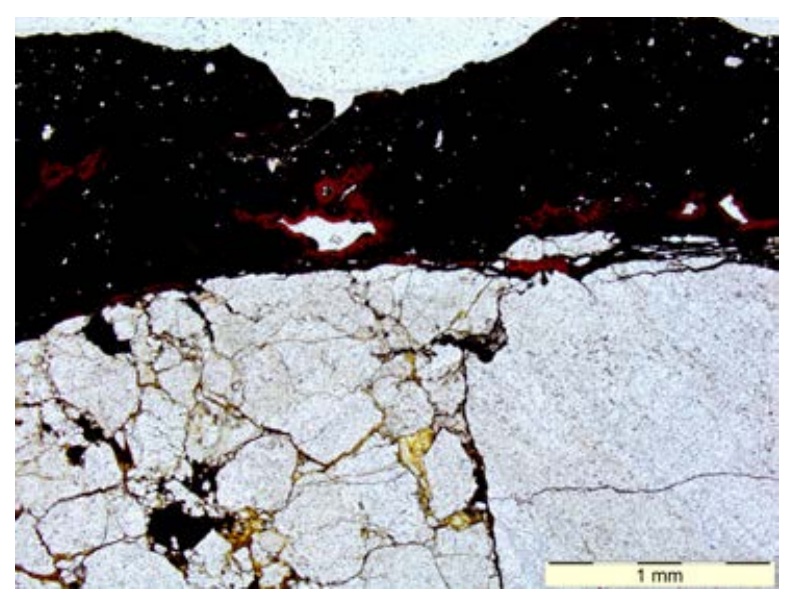

Fig. 7. Annaberg. PLM, one polarizer

Beveaux (Switzerland). On the surface on the pelitic-aleuritic iron rich rock, derived from the morainic area of the Neuchatel Lake shore, a dark red coat of a constant thickness of approximately $0.5 \mathrm{~mm}$ was formed. Microscopically, red shade is unevenly distributed, with the lower part of the layer darker than the upper. Structurally the layer is very similar to the ground and contacts with it rather sharply (Fig. 8).

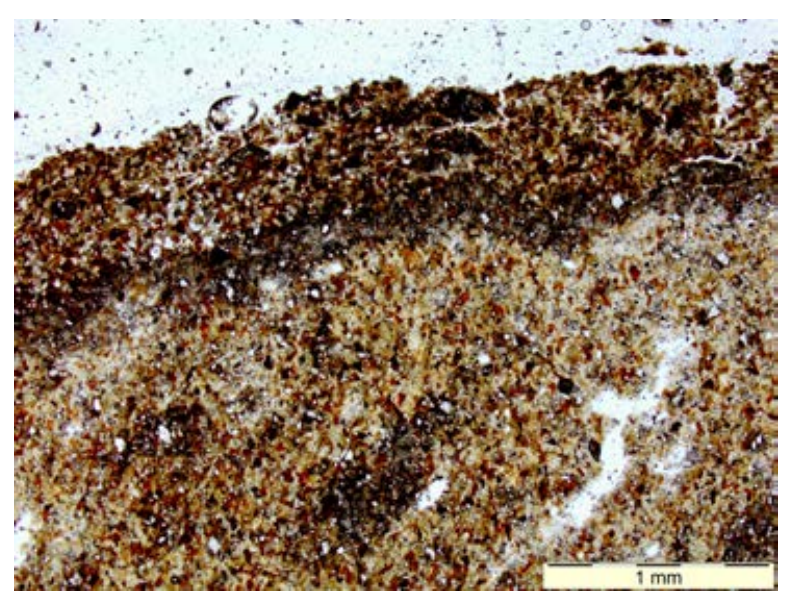

Fig. 8. Beveaux. PLM, one polarizer

Kasina Wielka (Poland). The sample comes from a clayey weathering crust on variegated slate of the Magura Unit. A dark red layer formed on the surface of the red rocks. Red layer, characterized by a more or less constant thickness of about $0.2 \mathrm{~mm}$, fine-grained structure and discontinuity, separates sharply from the underneath of the parental rock. The layer is homogeneous in terms of the composition. 


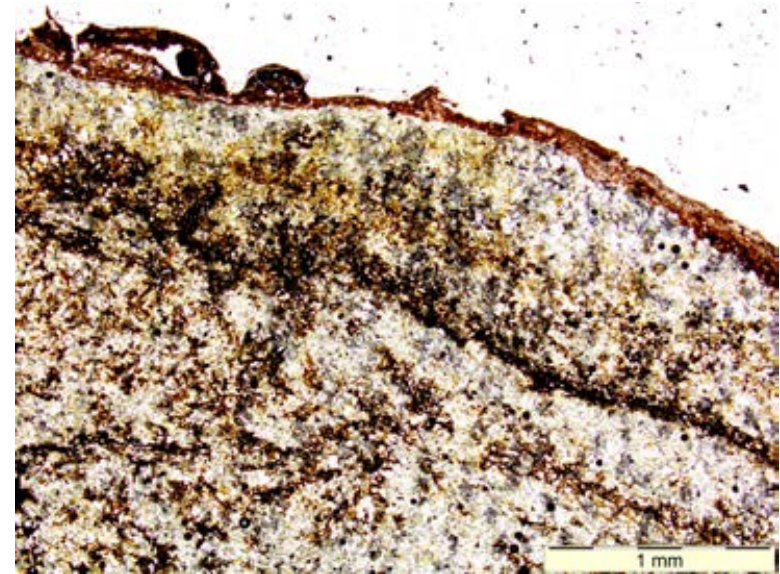

Fig. 9. Kasina Wielka. PLM, one polarizer

High concentration of iron compounds, compared to the parental rock might suggest the resemblance to painting layers (Fig. 9).

The Tatra Mountains - Strążyska (Poland). The sample is a pebble from the Strazżyski Stream. The surface of the sample is almost completely covered with cherry coating of cryptocrystalline iron compounds. The rock was deformed by sedimentary or metamorphic processes. Iron compounds are accumulated in the rock in the form of irregular streaks. Weathering processes resulted in the migration and accumulation of iron compounds on the surface of the pebble. The covering layer filled pebble's irregularities. Contact of the layer with the ground is very sharp and it penetrates deep into the surface of the pebble and into microcracks. In consequence, the components of the primary rock are immersed in the red crust.

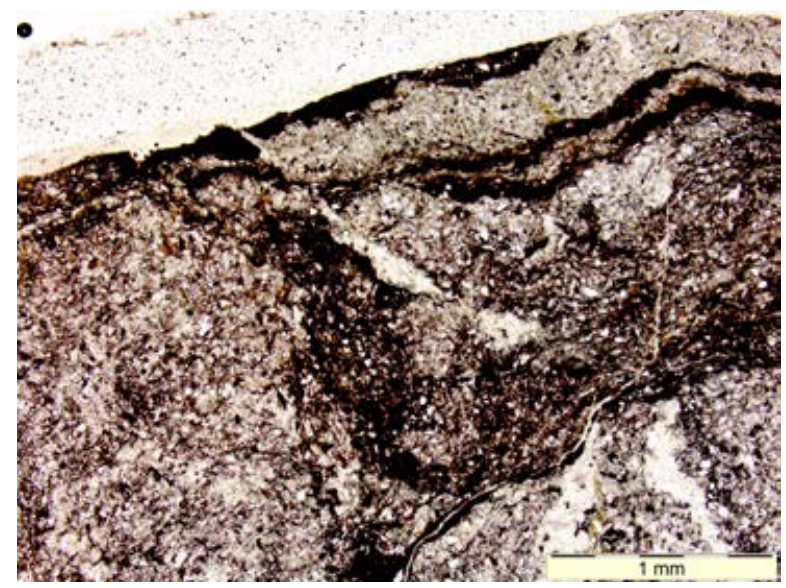

Fig. 10. The Tatra Mountains - Strążyski Stream. PLM, one polarizer
It is worth noting that the surface is very wellsmoothened by natural processes. Layer thickness is uneven, up to $0.2 \mathrm{~mm}$ (Fig. 10).

Jawor-Bolków (Poland). The sample comes from clayey weathering crust formed on the eruptive rocks of the Rotliegend.

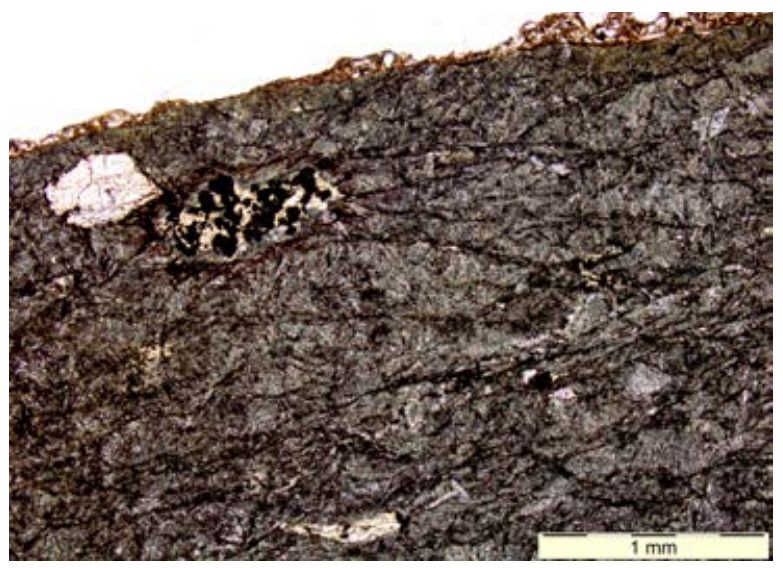

Fig. 11. Jawor-Bolków. Explanations in the text. PLM, one polarizer

The most external surface layer is a red-colored soil originated on volcanic rocks substrate. Red layer as a whole is characterized by diverse thickness. Phase composition also varies: detritic grains are submerged in cryptocrystalline iron unions. Contact with the parental rock is sharp. Patchy concentrations of iron compounds form opaque stripes within the volcanic glass. On the surface, they form a very thin layer under the soil dirt. This cover is discontinuous, very thin, and has a sharp contact with the ground (Fig. 11).

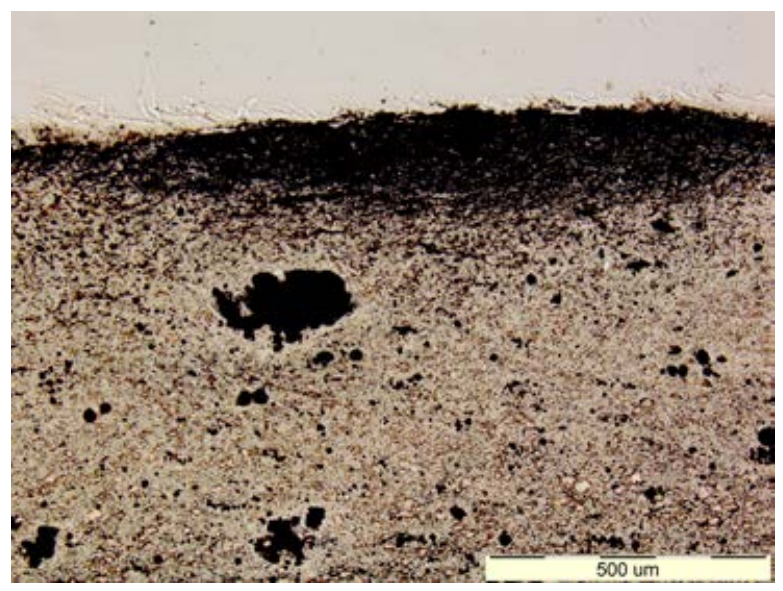

Fig. 12. Jaroszowiec. Explanations in the text. PLM, one polarizer 
Jaroszowiec (Poland). The sample represents a cherry micritic dolomite. In the rock volume, opaque rectangular phases are distributed; the thick, lenticular and uneven cherry crust formed on the rock surface is also composed of the same phases. The contact with the ground is blurred (Fig. 12). The most probably, the opaque grains are pyrite, weathered to hematite during warm and/or dry geological periods.

Brno (Moravia, Czech Republic). The sample represents a trachyandesitic or trachybasaltic pebble from Devonian conglomerate with a cherry surface, homogeneous, $0.2 \mathrm{~mm}$ thick. Surface layer is quite smooth. Contact with the rock substrate is sharp but uneven. The layer is homogeneous in terms of the composition, with occasional plagioclases (Figs 13, 14).

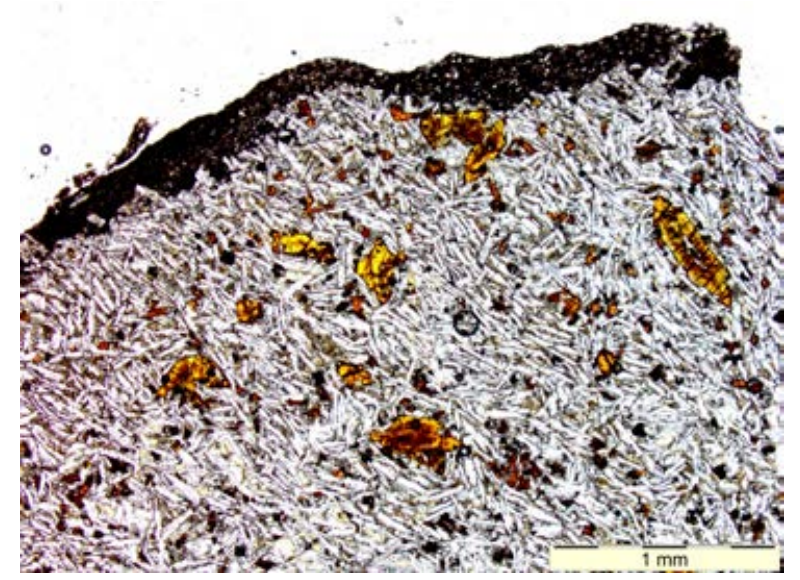

Fig. 13. Brno. Explanations in the text. PLM, one polarizer - sample 1

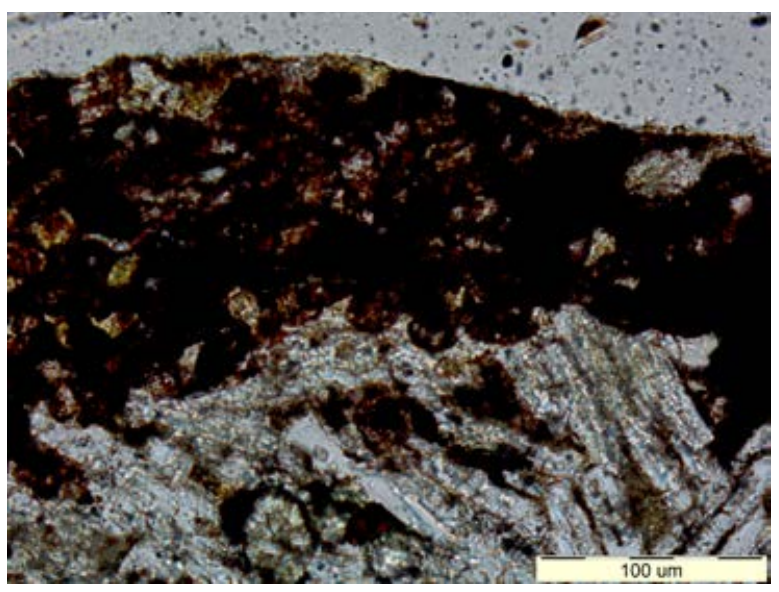

Fig. 14. Brno (a detail). Explanations in the text. PLM, one polarizer-sample 2

\section{Context well defined, the origin of the layers unclear}

A case: a red layer on the surface of the skull, Brno II site. The Upper Paleolithic Brno II site was discovered in the late $19^{\text {th }}$ century in one of the districts of Brno and re-explored in the second half of the $20^{\text {th }}$ century. It was located on the sands and gravels of the Svitava River floodplains, covered with loess, close to various crystalline and carbonates rocks. Bones of mammoth, rhinoceros and humans, and stones were found there. Human bones were colored red. The sample skull belonged to a man known as a shaman; the skull surface was covered with a number of notches (Oliva 1996).

Small fragments of the skull bones were collected in the Anthropos Museum in Brno. The bone is gray, covered one-side by a thin red layer. The layer does not flake off, adheres well to the ground (Fig. 15). The surface of the skull under the red layer is different from the surface of a modern man skull as well as Neolithic humans (Simel'nikov 1963, Tab. 48; 51n). In addition, this surface is not smooth and is barb (Figs 15, 16).

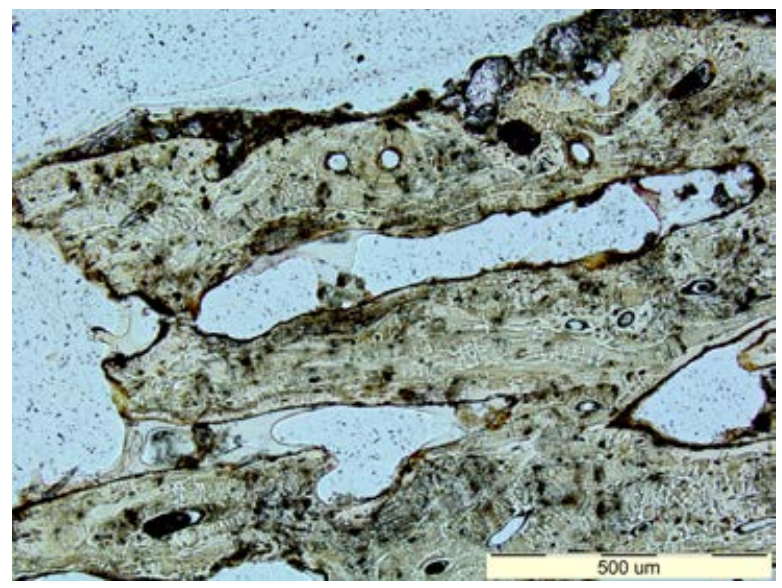

Fig. 15. A fragment of the skull surface with a red layer that fills the uneven ground. PLM, one polarizer

Colorful layer adheres to this surface filling microscopic inequalities (Figs 15, 16). The layer is not continuous and of a variable thickness, but not exceeding $0.5 \mathrm{~mm}$; it is grainy but homogeneous as far as the mineral composition is concerned. Irregular concentrations of oxides and/or iron hydroxides, angular clumps of calcium carbonate and clay minerals in lumps and rock matrix were detected (Fig. 16). In terms of chemical 


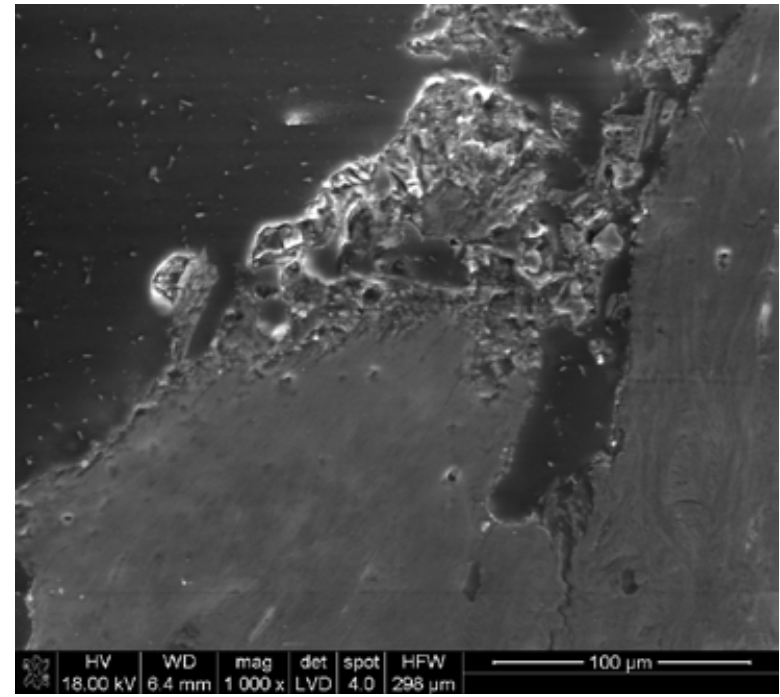

Fig. 16. Unevenness of the skull surface. An arrow points at calcium phosphate (bone, most probably) grain. Magnification $1000 \times$

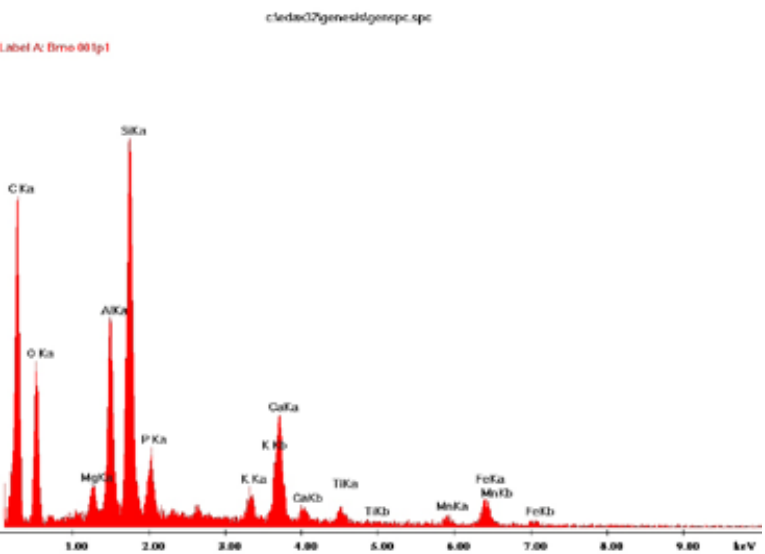

Fig. 17. EDS spectrum. Composition of clayey areas of the red layer

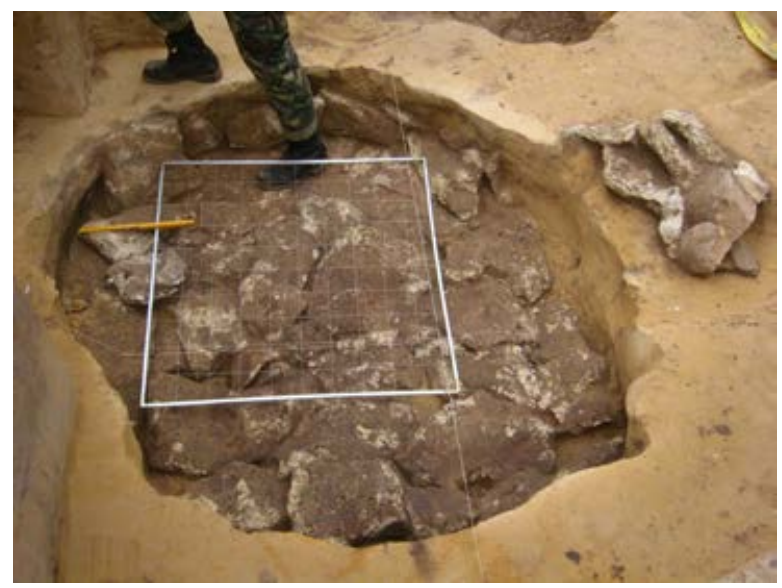

Fig. 19. Grave pavement covered with a red coating composition magnesium and potassium alumosilicates as well as iron phases are present (Figs 17, 18). A small amount of phosphorus in a form of dispersed, very cryptocrystalline (Fig. 17) phase(s) as well as single angular lumps, situated close to the surface of the skull (Fig. 16) were observed everywhere within the red layer.

A case: red crust on a stony pavement. A pavement (Fig. 19) was a part of the Neolithic Złockie Culture's grave, located at the Książnice site (Poland). The site occupied Quarternary loess of the Pińczów Hills, with a watercourse located about 300 m westwards. The tombs were constructed as burial niches and the near-niche pits. Skeletons and grave goods (pottery and objects made of stone and horn are located at a depth of 125-145 cm (Wilk et al. 2011).

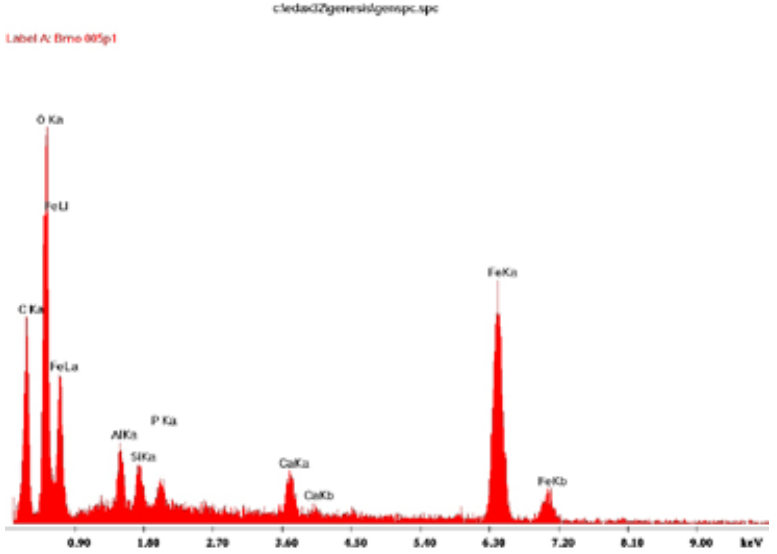

Fig. 18. EDS spectrum. Composition of iron compounds concentration within the red layer. Note a high concentration of alumina, compared to silica

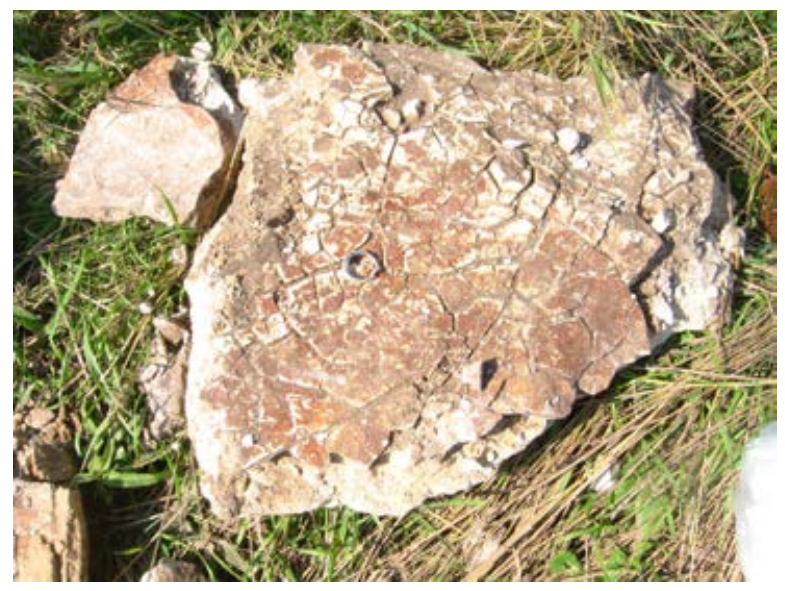

Fig. 20. One of the stones of the pavement 
The bottom of the niche is covered with white stone; the artifacts were distributed over its surface. The surface of the stone is red-orange, continuous or cracked (Fig. 20).

At the site, migration phenomena of iron compounds are common and result in yellow-orange streaks on the profiles' walls and compact crusts on the loose pebbles. Pavement stones include opokas and spikulites (Figs 19, 20).

An explanation of the red film nature on the pavement surface was especially important due to the context of sacred space and a fact of transporting the stone from a distance of ca. $20 \mathrm{~km}$ (Walczowski 1978).

Red and orange layers are characterized by a uniform thickness not exceeding $0.5 \mathrm{~mm}$, very good adherence to the ground and a "cloudy", soft contact with it (Figs 19, 20, 22, 23). They are entirely cryptocrystalline; its surface is smooth (Figs 19, 21) or uneven (Figs 20, 22). Within the visible layers, there are tiny fragments of the underlying rock (Figs 21, 23). The bedrock was discolored (Fig. 19) on the thickness of about $0.5 \mathrm{~mm}$.

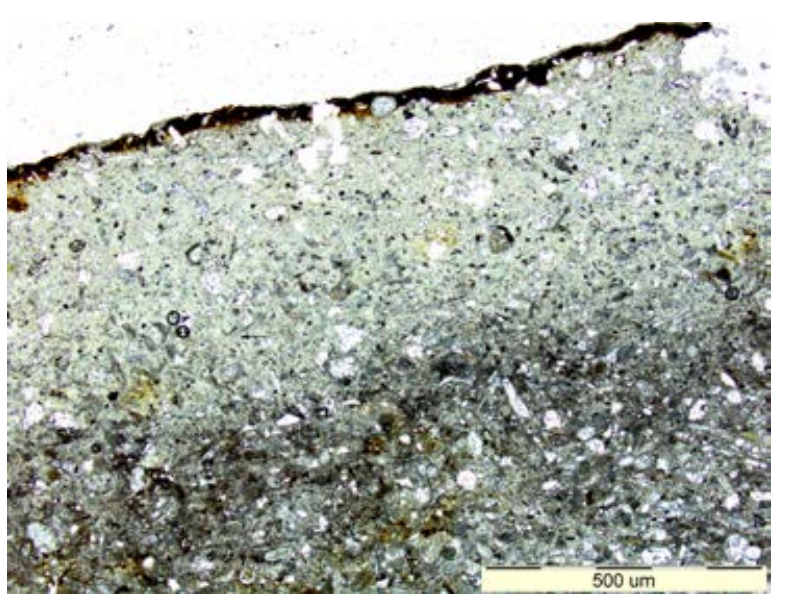

Fig. 21. Red layer on the surface of the calcitic opoka. PLM, one polarizer

PLM and SEM image reveals fine-grained and homogeneous appearance of the layer surface (Figs 23, 24). Its morphological diversity is revealed under a greater magnification: corroded authigenic quartz crystals (Fig. 25, p. 1) and oval agglomerates of silica are present. There are also concentrations of silica enriched in aluminum, magnesium, potassium and iron (Fig. 25, p. 3). Everywhere the amount of iron is very low (Figs 26, 27).

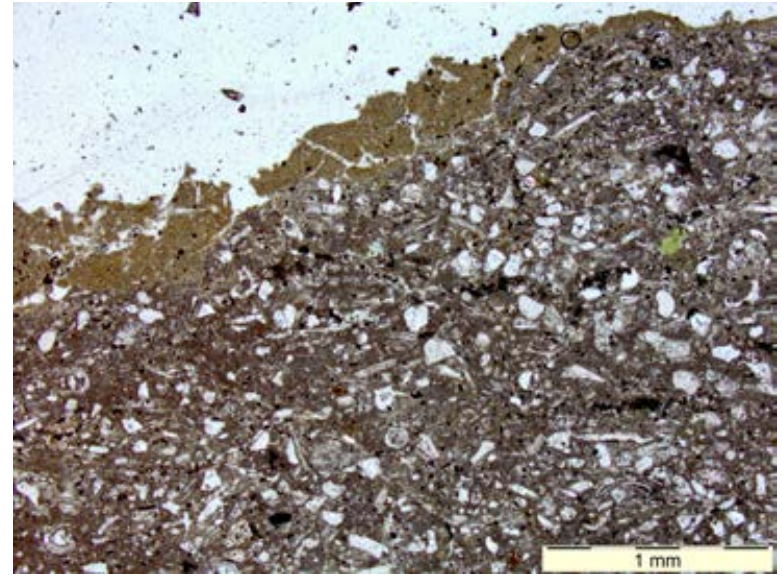

Fig. 22. Yellow-brown, cryptocrystalline crust on the opoka surface. PLM, one polarizer

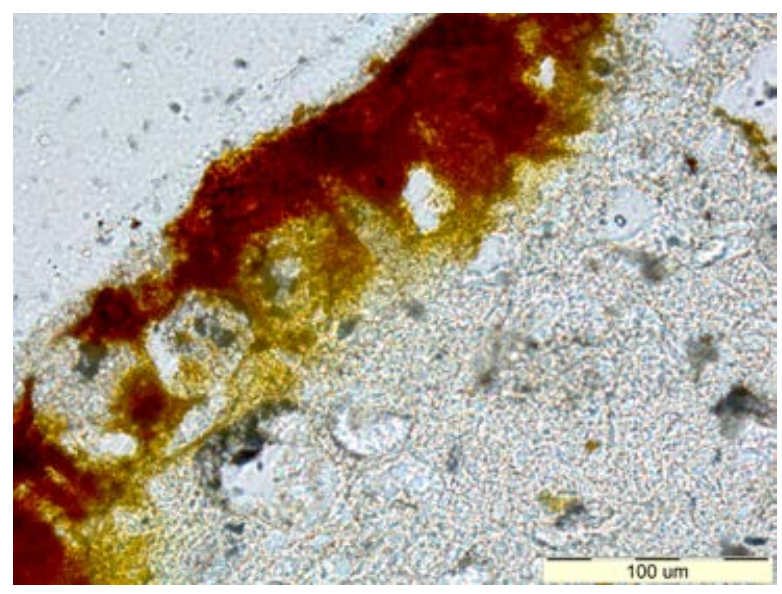

Fig. 23. Red crust with grains of primary rock. The crust is uniformly cryptocrystalline. PLM, one polarizer

A case: red layer on the surface of the bone. A bone fragment originates from the site Gać near Przeworsk (Subcarpathia, Poland), representing the Przeworsk Culture. It was found in the cremation gravesite, which was located on clay; it was an arable land at the time of the first exploration. Burial is situated on "a vast clayey plateau with slopes falling toward the low-lying meadows". Burnt bones were placed in urns and put into pits dug in the yellow clay, surrounded and covered with ashes, dusty burnt clay, shells and twisted iron weapon (Hadaczek 1909).

The bone was found in a grave, besides equipped with 5 iron items (inter alia, umbo and scissors), tentatively dated to phase B2 of the Roman Period (Anna Lasota, unpublished). The bone fragment is covered with a red layer, macroscopically uniform, well adhering to the substrate. 


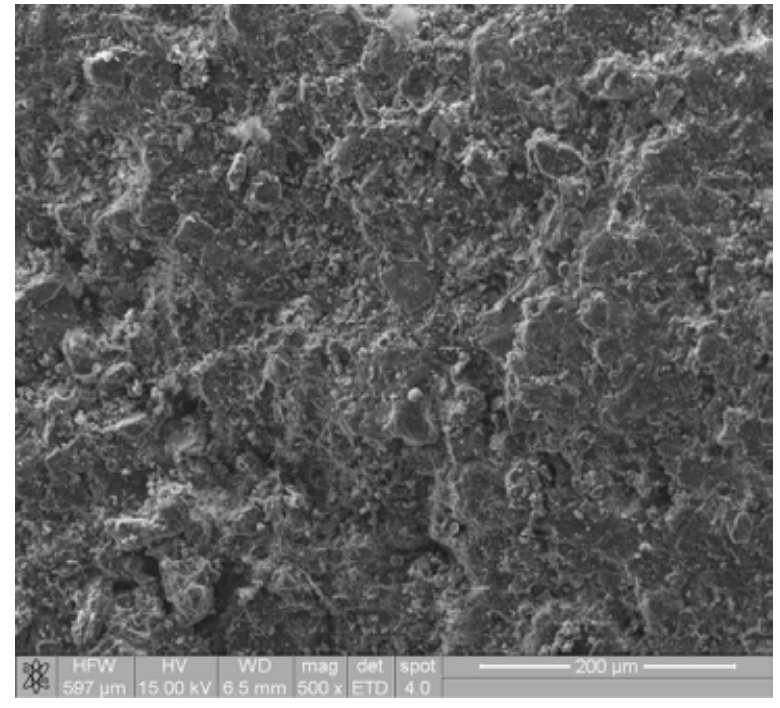

Fig. 24. Homogeneous and fine-grained red surface layer. Magnification 500×

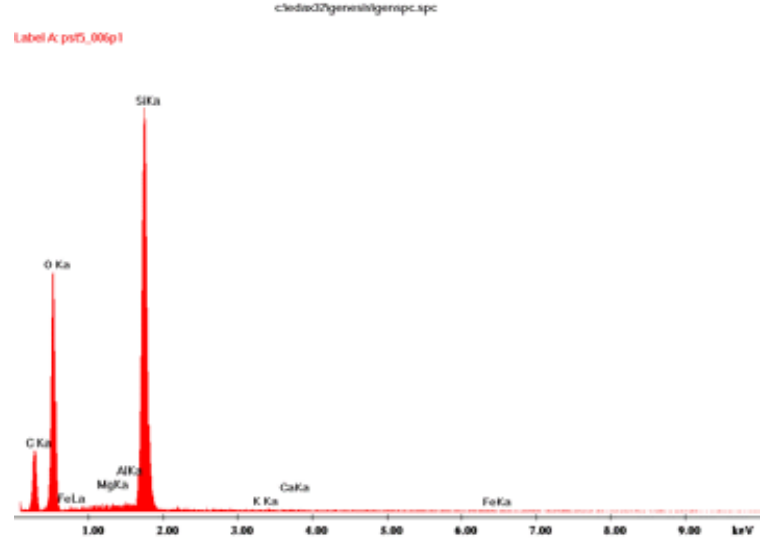

Fig. 26. EDS spectrum. Chemical composition of the surface in points 1 and 3

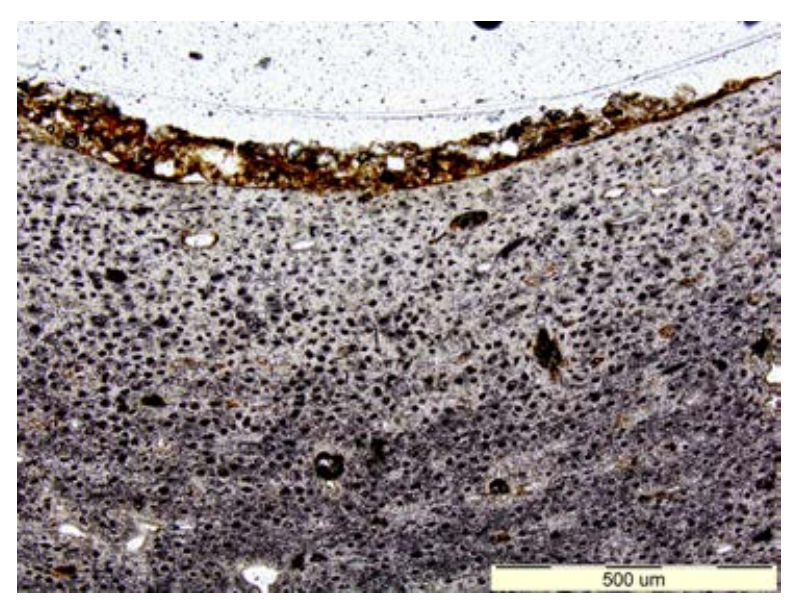

Fig. 28. Heterogeneity of the layer A. PLM, one polarizer

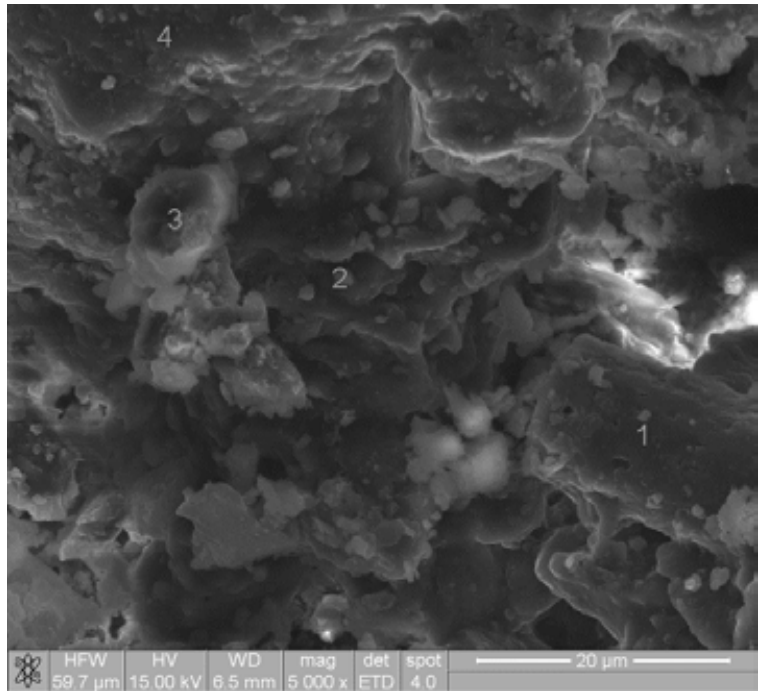

Fig. 25. The red surface composed mainly of silica and a small amount of iron. Magnification 1500x

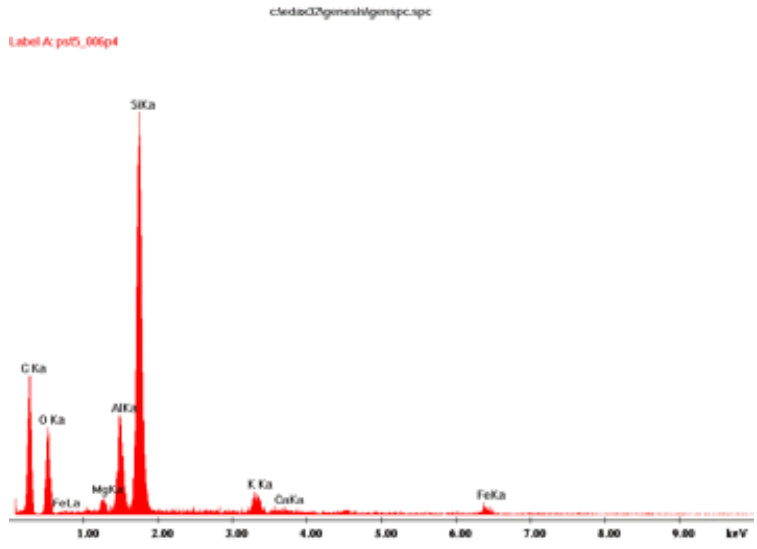

Fig. 27. EDS spectrum. Chemical composition of the surface in points 2 and 4

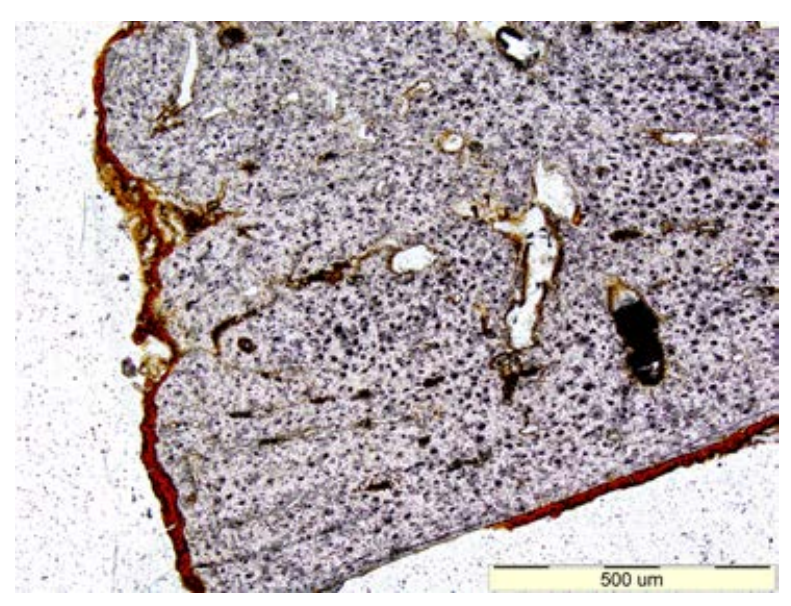

Fig. 29. Layer B: present on all surfaces of the bone. PLM, one polarizer 


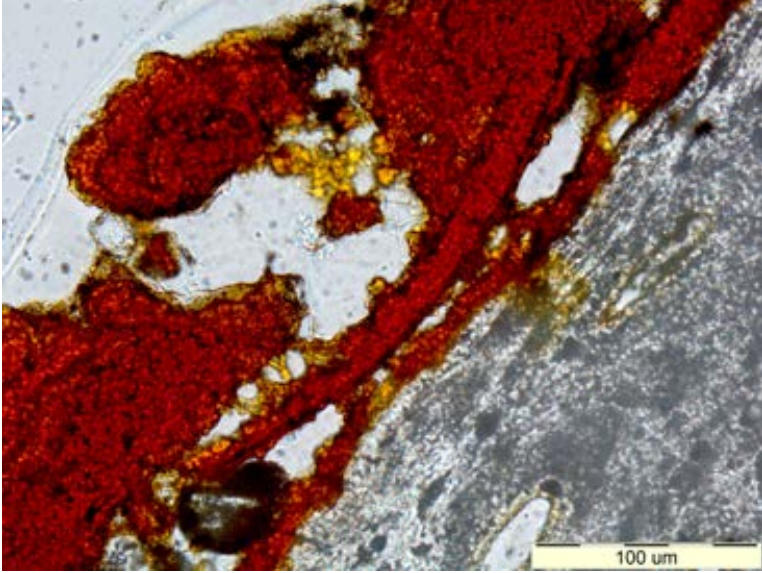

Fig. 30. Layer B. Collomorphic and crusty appearance of the layer. The bacterial (?) threads close to the bone surface. PLM, one polarizer

The crust is located on the external and internal parts. Red layer has three appearances; therefore, it will be further described as layer A, B and C.

Layer $\mathrm{A}$ is characterized by thickness not exceeding $0.2 \mu \mathrm{m}$; it sticks well to the smooth bone underneath; it is homogeneous in terms of composition and phase but multiphased (Fig. 28). Pores and channels are filled with an opaque substance (ash?) and iron compounds. The layer A is present only on the inner side of the bone.

Layer B reveals a diverse thickness; it is cryptocrystalline and homogeneous. It covers both internal and external surfaces of the bone (Fig. 29). It is characterized by flaky, crusty and collomorphic constitution with threads of bacterial or fungi origin (Fig. 30). The layer is bipartite (Fig. 31).

Layer $\mathrm{C}$ is characterized by a homogeneous, cryptocrystalline, fine granular morphology, the thickness of about $0.1 \mathrm{~mm}$, cracks perpendicular to the substrate, sometimes the presence of granular substances within a layer or between the layers of a bone.

\section{Discussion of dubious cases (the Brno II, Książnice and Gać sites)}

Identification of the origin of a red layer on the surface of the skull from the Upper Paleolithic Brno II site is compelling due to the fact of deliberate damage of the skull surface and the likely redeposition of the remains of the deceased (Oliva 1996). The layer morphology indicates that presumably a raw, non-processed, material was used: a natural mixture of fine-grained detritic quartz,

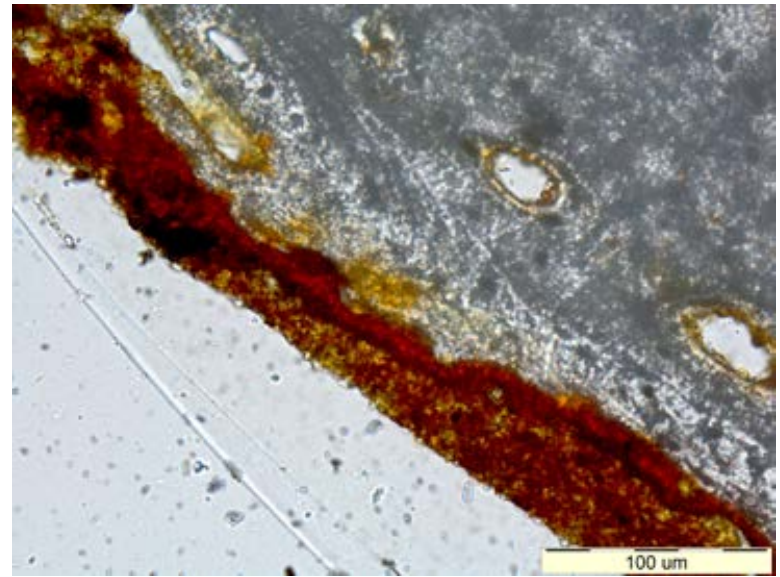

Fig. 31. Layer B. Bipartite layer. PLM, one polarizer

clay minerals and cryptocrystalline compounds of iron. Small lumps of calcium carbonate may indicate a genetic relationship with a carbonate rock, although the contamination from the surrounding loess cannot be ruled out (although, in fact, its chemical composition is unknown to us). High concentration of aluminum suggests the influence of alite weathering of a raw material, which is why the occurrence of terra rosa is probable.

Presence of grains of calcium phosphate in the red layer may indicate the rubbing of paint into the surface of the skull. However, accidental scaling off a bone fragment from the damaged skull surface cannot be ruled out.

A hypothesis about the natural origin of the red layer may be supported by its morphological similarity to natural dirt (Fig. 11). However, such red agglomerates (natural or burnt) have not been evidenced in the site's vicinity (Oliva 1996); additionally, only an external skull surface is reddened. Micromorphology of the red layer resembles the micromorphology of the painting from Vrbnik (Figs 1,2) or the experimental immersion (Figs 3,4$)$. No traces of an action of painting could have been proven but other modes of color application were possible (rubbing a roughly prepared red powder into the skull surface or application of a thick suspension).

Due to the intentional transport of stone slabs and their careful organization on the grave floor at the Książnice site it may seem that the red layer on a stony pavement should have been painted purposely. Environmental and morphological 
reasons suggest, however, that this is a layer of natural origin. The environment, in which the grave is located, is loess, where iron compounds have been migrating. Calcitic opoka, relatively easily soluble in weakly acidic environment, changes $\mathrm{pH}$ on the slab surfaces into neutral or alkaline. These conditions contribute to dissolving and reprecipitation of silica (documented on the Figure 25), adsorptive for iron compounds. Debris of opoka from underneath was immersed in uniformly cryptocrystalline red and orange crust; it is characteristic for the crust of natural origin.

Nevertheless, without detailed observations, nature of the layer may have been misinterpreted. Characteristics of the red layers on a bone from the Gać site, labeled as A, B, C, indicate that they are of natural origin. It might be confirmed by a cover on all the surfaces of the bone and especially by the collomorphic, uniform nature of iron compounds of layers B and C. In turn, layer A, with inhomogeneous structure, fills the bone from the inside. The substance within layer $\mathrm{A}$ and partially layer $\mathrm{C}$ is similar to the mineral soil or/and ash contamination. Therefore, it seems probable that a layer of iron oxides and/ or hydroxides closes the mineral dirt and likely some post-cremation contaminants. Variety of morphology of red layers suggests their formation at different times. Dried up layer $\mathrm{C}$ seems to be older than layer $\mathrm{B}$; it is hard to determine the age of layer A. Iron compounds may have originated either from the surrounding rocks or corroded iron objects, unless the latter were covered with fire patina (sealed with a layer of hematite).

\section{DISCUSSION AND SUMMARY}

Painting layers of any age, when a mineral pigment is used, are characterized by, more or less, a thickness of $0.2 \mathrm{~mm}$ and a detectable, usually sharp contact with the ground. Paints can penetrate into the substrate when they are too thin or ground is too wet. Painting layers, especially younger than Paleolithic, were usually executed on a prepared underneath. If grains of pigments can be detected under a high-magnification PLM, they reveal a uniform size and shape. Usually, there are no impurities associated with raw materials or their amount is low but intentional extenders may have been present. Organic adhesives can often be evidenced in historical paintings (e.g. Roy 1993, Berrie 2007); their identification is more complex in archaeological painting and other layers. When carefully processed, the separate components of paint may be detected, only with difficulty, under PLM; scanning microscope is more effective. Painting layers may be deteriorated, subsequently their continuity is usually lost but even then they may be identified (Fig. 2).

If red layers were not a result of a painting action but spraying a red powder on a surface, rubbing it in dry into it, or applying a suspension, some above-mentioned features may disappear; especially a careful paint preparation, among others grinding pigments or addition of extender according to determined recipes.

Colorful layer obtained in the experiment is characterized by a uniform thickness not exceeding $0.2 \mathrm{~mm}$. The layer penetrates into the ground, fills pores of bones and smoothens unevennesses. Although levigation process was applied, clay minerals and detritic quartz grains are still detectable, indicating the type of raw material (Figs 3,4). They differ from natural crusts (Fig. 28) in their multiphase structure, lack of organogenic remains and lack of deep penetration into a bone pores. In most cases, the natural layers are cryptocrystalline.

Natural layers on rocks are of diverse thickness, different structural similarity to the substrate (extreme examples include Annaberg and Beveaux; Figs 9, 10), various contact with the ground. In most cases, the crusts are composed of cryptocrystalline iron compounds, frequently with incorporated fragments of underlying, parental rocks. Sometimes (sample Jawor-Bolków) natural crust overlaps with a layer of dirt from the environment, in this case also red. Sometimes red crusts are delusively similar to intentionally executed crusts (compare Figs 11 and 15).

Therefore, several criteria, that allow to discern natural and intentional red layers in dubious cases, in accordance with the premise of the work, can be proposed (Tab. 2).

\section{FINAL CONCLUSIONS}

The cryptocrystallinity and continuity are mostly (but not always) the features that apparently indicate a natural origin of red layers. 
Table 2

Specific features of intentional and natural red layers

\begin{tabular}{|c|c|}
\hline Example & Specific features \\
\hline $\begin{array}{l}\text { Paintings on a } \\
\text { prepared underneath }\end{array}$ & $\begin{array}{l}\text { Layers are narrow, of a uniform thickness, close to } 0.2 \mathrm{~mm} \text {. } \\
\text { Painting layer is usually structurally homogeneous. } \\
\text { Contact with the ground is usually sharp. } \\
\text { Cloudy penetration of a red layer into an underground is possible. } \\
\text { Specific extenders may be present. } \\
\text { Textural (parallel, wavy) indicators of a painting process may be detectable. } \\
\text { Possible fillings of cracks of an underground by a red layer are possible. } \\
\text { An underground is usually intentionally prepared. } \\
\text { Pigments in PLM image are very small or invisible. } \\
\text { Pigments micromorphology, hematite ordering and chemical composition may (but not necessarily) } \\
\text { differ from the analogous features of natural weathering crusts from the surroundings }\end{array}$ \\
\hline $\begin{array}{l}\text { Paintings on a rough } \\
\text { underneath }\end{array}$ & $\begin{array}{l}\text { As above, but: } \\
\text { an underground may be unprepared (usually cave, rock and stone paintings), } \\
\text { a painting layer may be wavy, discontinuous (as above) }\end{array}$ \\
\hline $\begin{array}{l}\text { Intentional layers } \\
\text { other than paintings }\end{array}$ & $\begin{array}{l}\text { Does not need to be continuous. } \\
\text { May be multiphased. } \\
\text { Red component does not need to have been prepared (e.g. ground). } \\
\text { May be of various thickness, but still not exceeding significantly } 0.2 \mathrm{~mm} \text {. } \\
\text { Underlayer is not intentionally prepared considering a painting action (e.g. smoothened). } \\
\text { A contact between a layer and underneath may be very irregular. } \\
\text { Specific features of an underneath or specific admixtures may be indicative }\end{array}$ \\
\hline Experimental layer & $\begin{array}{l}\text { Homogeneous and compact layer. } \\
\text { Penetrates into the porous substrate (due to quite thin suspension). } \\
\text { Raw material features possible to decipher. } \\
\text { Layer thickness comparable with painting layers }\end{array}$ \\
\hline Natural crusts & $\begin{array}{l}\text { Homogeneous crust often structurally resembles an underneath. } \\
\text { Contact with the ground varies (is "cloudy" or very sharp). } \\
\text { Remnants of a parental rock may be included into crusts. } \\
\text { Thickness may be identical as for painting layers. } \\
\text { Compactness may be identical as for painting layers. } \\
\text { Very irregular thickness is possible. } \\
\text { Scaling off is possible. } \\
\text { Collomorphic appearance is very common }\end{array}$ \\
\hline
\end{tabular}

Based on the discerned criteria (Tab. 2) we have classified a red layer on a surface of a bone from the Gać site and the Książnice site as natural, a red layer on a shaman skull from the Brno II site as intentional. In all cases, we have also analyzed environmental factors promoting a mobility of iron compounds as well as geological setting. Composition of red layers may indicate a determined raw material, or, at least, material that does not occur in the object's vicinity. Criteria of thickness and a variety of a contact with the ground as well as smoothness of a surface are not decisive: many natural layers are confusingly similar to intentional layers. The possibility of overlapping of several crusts or painting layers and crusts cannot be neglected. We have observed the phenomenon for a "natural" sample (sample Jawor-Bolków) and a sample originated from a site (Gać); the latter recognized also as a natural. It should be remembered that colored layers of any origin may bear information on surroundings.

\section{REFERENCES}

Behrmann R. \& Gonzales J., 2009. Les colorants de l'art paléolithique dans les grottes et en plein air. L'Anthropologie, 113, 559-601.

Berrie B. (ed.), 2007. Artists' Pigments. A Handbook of Their History and Characteristics. Vol. 4. Washington - London. 
Broglio A., Giachi G., Gurioli F. \& Pallecchi P., 2007. Les peintures aurignaciennes de la grotte de Fumane. [in:] Floss H. \& Rouquerol N. (eds), Les chemins de l'art aurignacien en Europe. Editions Musée-forum Aurignac, Cahier 4, 157-170.

Chiotti L., Delluc B. \& Delluc G., 2007. Art et parure aurigneciens de l'Abri Pataud (Les Eyzies-de-Tayac, Dordogne, France) dans le contexte aurignacien du Perigord. [in:] Floss H. \& Rouquerol N. (eds), Les chemins de l'art aurignacien en Europe. Editions Mesée-forum Aurignac, Cahier 4, 171-185.

Dobosi V.T., 2006. Lovas (Hungary) ochre mine reconsidered. [in:] Körlin G. \& Weisgerber G. (eds), Stone Age Mining Age. VIII Internationales Feuerstein Symposium im Deutschen Bergbau Museum Bochum 1999. Veröffentlichungen aus dem Deutchen Bergbau Museum Bochum 148/Der Anschnitt Beih, 19 (Bochum 2006), 29-36.

Hadaczek K., 1909. Cmentarzysko ciałopalne koło Przeworska [series: Teka Konserwatorska, 3, 2). Grono C.K. Konserwatorów Galicyi Wschodniej, Lwów.

Hernanz A., Ruiz-Lopez J.F., Gavira-Vallejo J.M., Martin S. \& Gavrilenko E., 2010. Raman microscopy of prehistoric rock paintings from the Hoz de Vicente, Minglanilla, Cuenca, Spain. Journal of Raman Spectroscopy, 41, 1394-1399.

Lejeune M., 2007. Le Trou Magrite et l'art mobilier aurignacien en Belgique: synthese et problemes. [in:] Floss H. \& Rouquerol N. (eds), Les chemins de l'art aurignacien en Europe. Editions Mesée-forum Aurignac, Cahier 4, 131-144.

Martin Y., 1993. Analyse des pigments. [in:] L'art Pariétal Paléolithique. Techniques et méthodes d'étude, Paris 1993, 261-264.

Odile M. \& Plassard J., 1995. Visiting Rouffignac Cave. Bordeaux.

Oliva M., 1996. Mladopaleolitycky hrob Brno II jako príspěvek k počátkum šamanismu. Archeologické rozhledy, 48, 3, 353-383.

Oliva M., 2007. Gravettien na Moravě. Praha - Brno.

Petru S., 2006. Red, black or white? The dawn of colour symbolism. Documenta Praehistorica, 33, 1-6.
Rosanò P. \& Pelizzaro S. 2005. Analisi chimico-stratigrafico di tre pietre dipinte con ocra. [in:] Broglio A. \& Dalmeri G. (eds), Pitture paleolitiche nelle Prealpi Venete. Grotta di Fumane e Riparo Dalmeri, Cierre Edizioni, Verona, 139-143.

Roussot A., 1994. Visiter le Cap Blanc. Bordeaux.

Roy A. (ed.), 1993. Artists' Pigments. A Handbook of Their History and Characteristics. Vol. 2. Washington - London.

Simel'nikov R.D., 1963. Atlas anatomii čeloveka. Tom 1: Učenie o kostâh, soedinenie kostej $i$ myšcah. Gosudarstvennoe izdatel'stvo medicinskoj literatury, Moskva - Leningrad.

Trąbska J. 2001. Mineralogical and chemical study of painting layers of Medieval wall paintings from Poland [series: Prace Mineralogiczne, 90]. Polska Akademia Nauk, Kraków.

Trąbska J., 2009. Microstructure of haematite powder: an udervalued indicator in interpretation of ferruginous raw material manufacuring, using and provenance. Ślaskie Sprawozdania Archeologiczne, 51, $5-13$.

Trąbska J. \& Gaweł A., 2007. Microstructural features of powdered haematite as a promising factor in provenance studies. Sprawozdania Archeologiczne, 59, 41-48.

Trąbska J., Trybalska B. \& Gaweł A. [in preparation]. Data Base of Red Ferruginous Raw Materials.

Walczowski A., 1978. Szczegółowa mapa geologiczna Polski w skali 1:50 000, arkusz Bejsce (949). Warszawa.

Wilk S., Haduch E., Szczepanek A., Koszowska E. \& Trąbska J., 2011. Groby z nadpalonymi szkieletami z cmentarzyska kultury złockiej w Książnicach, woj. świętokrzyskie. [in:] Jaszewska A. \& Michalak A. (red.), Ogień - żywioł ujarzmiony i nieujarzmiony. VI Polsko-Niemieckie Spotkania Archeologiczne, Garbicz, 5-6 czerwca 2008 r., Stowarzyszenie Naukowe Archeologów Polskich. Oddział Lubuski, Zielona Góra, 23-54.

http://www.geology.cz/app/ciselniky/lokalizace/show_map. php? mapa $=$ g50zj\&y $=597467 \& \mathrm{x}=1160307 \& \mathrm{r}=7500 \& \mathrm{~s}=1$ \&legselect $=0$. 